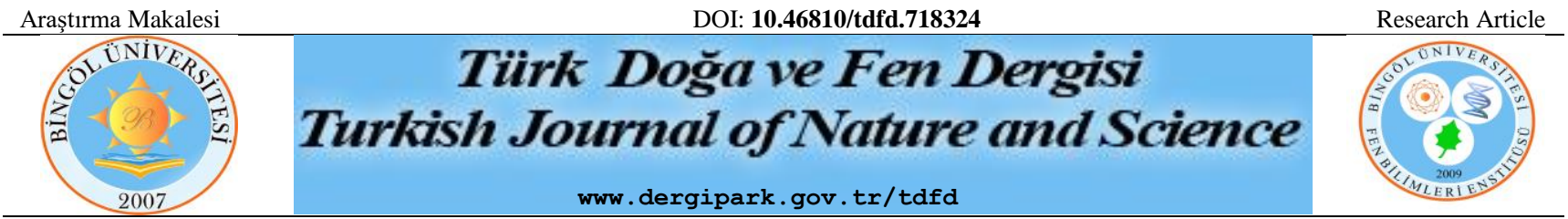

Phillyrea latifolia L. :Biological Properties Screening of Different Extracts

\author{
Sengul UYSAL ${ }^{1,2 *}$ \\ ${ }^{1}$ Erciyes University Halil Bayraktar Health Services Vocational College, Kayseri, Turkey \\ ${ }^{2}$ Ziya Eren Drug Application and Research Center, Erciyes University, Kayseri, Turkey \\ Sengul UYSAL ORCID No: 0000-0003-4562-1719 \\ *Sorumlu yazar: senguluysal@erciyes.edu.tr
}

(Alınış: 11.04.2020, Kabul: 31.05.2020, Online Yayınlanma: 18.06.2020)

Keywords

Cholinesterase,

Diabetes,

Phillyrea,

Polyphenols,

Tyrosinase

\begin{abstract}
Phillyrea latifolia L. is widely used as astringent, diuretic and hypoglycaemic in Mediterranean traditional medicine. This work focused on the biological properties (antioxidant and enzyme inhibitory) of $P$. latifolia L. leaves extracts, obtained by different solvents (ethyl acetate, methanol and aqueous). The amount of phenolics and flavonoids in P. latifolia L. extracts was also assessed by spectrophotometric methods. The methanol extract showed the highest total flavonoid content (68.07 $\mathrm{mg} \mathrm{RE}^{-1}$ ). The ethyl acetate extract exhibited stronger DPPH radical scavenging activity $\left(190.71 \mathrm{mg} \mathrm{TE} \mathrm{g}^{-1}\right)$. The best CUPRAC activity was shown by the methanol extract $\left(609.38 \mathrm{mg} \mathrm{TE} \mathrm{g}^{-1}\right)$. The aqueous extract $\left(14.83 \mathrm{mg}\right.$ EDTA $\mathrm{g}^{-1}$ ) displayed the highest activity in metal chelating assay. Results showed that ethyl acetate extract indicated the highest activity in enzyme inhibition tests. Considering the obtained data, $P$. latifolia L. has potential to be used as sources of natural antioxidant and enzyme inhibitor
\end{abstract}

\title{
Phillyrea latifolia L: Farklı Ekstraktlarının Biyolojik Özelliklerinin İncelenmesi
}

Anahtar
Kelimeler
Diyabet,
Phillyrea,
Polifenoller,
Kolinesteraz,
Tirozinaz

Öz: Phillyrea latifolia Akdeniz geleneksel tıbbında kanamayı durdurucu, diüretik ve hipoglisemik olarak yaygın şekilde kullanılmaktadır. Bu çalışma farklı çözücülerle (etil asetat, metanol ve su) elde edilen $P$. latifolia L. yapraklarının biyolojik özellikleri (antioksidan ve enzim inhibitör) üzerine odaklanmıştır. Ayrıca, P. latifolia L. ekstraktlarındaki fenoliklerin ve flavonoidlerin miktarı spektrofotometrik yöntemlerle değerlendirildi. Metanol ekstrak yüksek toplam flavonoid

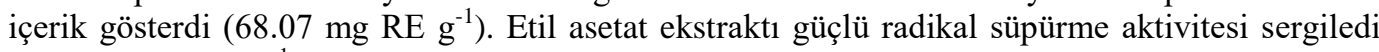
(190.71 mg TE $\left.\mathrm{g}^{-1}\right)$. En iyi CUPRAC aktivitesi methanol ekstraktı tarafindan gösterilmiştir $\left(609.38 \mathrm{mg} \mathrm{TE} \mathrm{g}^{-1}\right)$. Su ekstraktı (14.83 $\mathrm{mg}$ EDTA g $^{-1}$ ) metal şelatlama deneyinde yüksek aktivite sergiledi. Sonuçlar etil asetat ekstraktı enzim inhibitor testlerinde yüksek aktivite gösterdi. Elde edilen sonuçlar göz önüne alındığında, $P$. latifolia L. yaprakları umut verici bir doğal antioksidan kaynağıdır ve bulaşıcı olmayan hastalıkların tedavisi için sağlıklı yararlar sağlayabilir.
Alzheimer's disease (AD) is neurodegenerative disorder, which is characterized by the progressive decline of memory and the progressive loss of cholinergic neurons $[8,9]$. However, there is no effective treatment for AD yet. The most prescribed drug for the symptomatic treatment of AD is cholinesterase inhibitors [10]. Diabetes mellitus (DM) is a major chronic noncommunicable and metabolic disease with hyperglycaemia [11-13]. In 2017 there were just over 451 million were diabetes and this figure is expected to rise to 693 million by 2045 [14]. At present, the most know therapeutic approaches for treatment of DM is inhibition of the $\alpha$-amylase and $\alpha$-glucosidase enzymes that are involved in digestion of carbohydrates [15]. 
Despite the current treatment strategy for abovementioned diseases is enzyme inhibitory (galanthamine for $\mathrm{AD}$, acarbose and miglitol for $\mathrm{DM}$, and kojic for skin disordes). it should be noted that the most commonly used drugs are limited by side effects (e.g., hepatotoxicity, gastrointestinal disturbances, diarrhea) [16-18]. Thus, screening phytochemical profile and pharmaceutical properties from plant for the discovery of new safe and effective drugs have gained considerable attentions.

Phillyrea latifolia L. is a Mediterranean maquis of the Oleaceae family [19]. This plant is used in Spanish folk medicine for the treat of ulcers, mouth inflammation, and as astringent, and diuretic agent [20]. Moreover, decoction and infusion of $P$. latifolia leaves are used for the treatment of kidney stones and as hypoglycaemic in Turkey [21]. Previous data on P. latifolia leaves have revealed the presence of iridoids, triterpenoid compounds, flavonoid glycosides, lignan, and phenylpropanoid [20,22,23]. Extracts and isolated compounds have indicated to possess anti-inflammatory and antibacterial activity [20,23,24].

Based on our literature search, there is very little knowledge on phytochemical profile and biological properties of $\mathrm{P}$. latifolia leaves. In this regard, the present study has attempted to investigate the antioxidant capacity and enzyme inhibitory effect as well as total bioactive compounds of $P$. latifolia leaves. After a thorough review, this is the first report to on the antioxidant potential and enzyme inhibitory effect of $P$. latifolia leaves.

\section{MATERIALS AND METHODS}

\subsection{Plant Materials}

The leaves of Phillyrea latifolia L. were collected in 2018 at Silifke, Mersin, Turkey. Plant material was identified by Dr. botanist Evren Yildiztugay from the Selcuk University. The leaves were dried at room temperature. Then, the dried leaves were grounded in a laboratory mill prior to extraction.

\subsection{Preparation of Extraction}

The dried materials (5 g) were macerated with ethyl acetate and methanol $(100 \mathrm{~mL})$ for $24 \mathrm{~h}$ at room temperature. Ethyl acetate and methanol extracts were evaporated by evaporation in vacuum at $40{ }^{\circ} \mathrm{C}$. To aqueous extract, powdered material $(5 \mathrm{~g})$ was boiled with distilled water for $30 \mathrm{~min}$. The aqueous extract was lyophilized. All samples were stored in a refrigerator for further analysis. The yield of the ethyl acetate, methanol, and aqueous extract was $7.75 \%, 16.16 \%$, and $30.37 \%$, respectively.

\subsection{Total Polyphenols and Flavonoids}

The phenols (TP) and flavonoids (TF) were evaluated by Folin- Ciocalteu and $\mathrm{AlCl}_{3}$ methods, respectively [25]. The results were expressed as gallic acid equivalents for
TP. The results were expressed as rutin equivalents for TF.

\subsection{Biological Activities}

The procedures of antioxidant capacity and enzyme inhibitory assays were given, described in our previously study [25].

\subsubsection{In vitro antioxidant assays}

Antioxidant capacity of $P$. latifolia leaves were assessed using different in vitro assays. The antioxidant results were expressed by using appropriate standard components: trolox for DPPH, ABTS, CUPRAC, FRAP, phosphomolybdenum; ethylenediaminetetraacetic acid for metal chelating.

\subsubsection{In vitro enzyme inhibitory assays}

The enzyme inhibitory potential of the extracts obtained from $P$. latifolia leaves were evaluated against cholinesterase, $\alpha$-amylase, $\alpha$-glucosidase and tyrosinase. The enzyme inhibition results were expressed by using appropriate standard components: galantamine for cholinesterase, kojic acid for tyrosinase, acarbose for amylase and glucosidase.

\subsection{Statistical Analysis}

One-way ANOVA and Tukey's post-hoc test with the confidence level of $95 \%$ were done to assess the difference among samples for each evaluated biological activities. All statistical analysis were performed using $\mathrm{R}$ software v.3.6.2.

\section{RESULTS AND DISCUSSION}

Polyphenols are significant compounds found in plants and they possess potential health effects with high antioxidant properties [26]. The total phenols (TP) and total flavonoids (TF) were assessed by using colorimetric assays and the results are shown in Figure 1 and 2. The ethyl acetate extract exhibited the highest TP (111.37 mg GAE $\left.\mathrm{g}^{-1}\right)$, followed by aqueous $(106.71 \mathrm{mg}$ $\mathrm{GAE} \mathrm{g}^{-1}$ ), and methanol (95.26 $\left.\mathrm{mg} \mathrm{GAE} \mathrm{g}^{-1}\right)$. The TF of different extract was ranged from 35.13-68.07 mg RE $\mathrm{g}$ ${ }^{1}$.Flavonoids are important group of phenolic compounds and possess multiple health-promoting effects [27]. The results obtained in this work indicated that the phenolic and flavonoids contents of P. latifolia leaves are strongly affected by the different solvent employed. As can be seen on Figure 2, methanol is suitable solvent for extracting total flavonoid content from P. latifolia leaves. According to Ayranc1 and Erkan [28], the methanol extract of $P$. latifolia fruit contained a high level TP

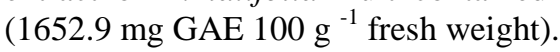

Many mechanisms have been suggested for the evaluation of antioxidant capacity in vitro. To this end several assays such as ABTS, DPPH, FRAP, CUPRAC, metal chelating and phosphomolybdenum are commonly employed to assess the antioxidant capacity of plants. 
Table 1 shows the total antioxidant properties of tested extracts. In DPPH assay, the ethyl acetate and methanol extract (190.71 and $184.77 \mathrm{mg} \mathrm{TE} \mathrm{g}^{-1}$, respectively) exhibited high scavenging activity. Nevertheless, aqueous extract (158.04 mg TE $\mathrm{g}^{-1}$ ) showed weak scavenging activity. Unlike the DPPH assay, the aqueous extract (347.40 $\mathrm{mg} \mathrm{TE} \mathrm{g}^{-1}$ ) showed higher ABTS radical scavenging activity compared to the other extracts. In the previously study, the methanol extract of $P$. latifolia fruits showed DPPH (IC50: $69.4 \mu \mathrm{g} \mathrm{ml}^{-1}$ ) and ABTS (1.8 mMTE $\mathrm{g}^{-1}$ ) radical scavenging activity [28]. These values are not comparable to the our results because of values were given in various units.

In the CUPRAC and FRAP tests, all extracts displayed similar activity. In CUPRAC assay, reducing power activity of extracts was in the range from 575.59 to $609.38 \mathrm{mg} \mathrm{TE} \mathrm{g}^{-1}$. The FRAP activity of extracts was in

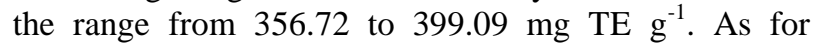
phosphomolybdenum assay, the highest total antioxidant activity was determined in ethyl acetate $(5.62 \mathrm{mmol} \mathrm{TE}$ $\left.\mathrm{g}^{-1}\right)$, followed by methanol $\left(3.93 \mathrm{mmol} \mathrm{TE} \mathrm{g}^{-1}\right)$ and aqueous (3.34 mmol TE $\mathrm{g}^{-1}$ ). The methanol and aqueous extracts showed metal chelating activity, whereas, ethyl acetate extract did not show any metal chelating activity. To the best of our knowledge, study on antioxidant capacity of $P$. latifolia leaves has not presented in literature.

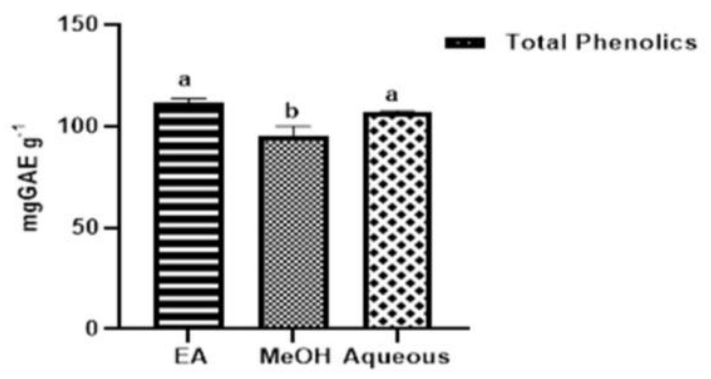

Figure 1. Total phenolic content of $P$. latifolia, GAE: gallic acid equivalents, For each solvent, values in the same column bearing different letters are significantly different at $\mathrm{p}<0.05$

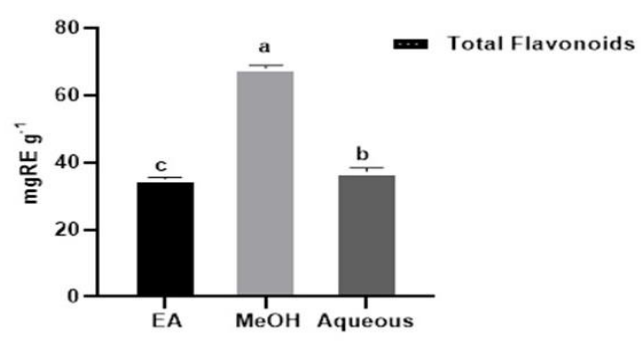

Figure 2. Total flavonoid content of $P$. latifolia RE: rutin equivalents, For each solvent, values in the same column bearing different letters are significantly different at $\mathrm{p}<0.05$

Enzyme inhibitors have long been an attractive strategy for the treatment of non-communicable including Alzheimer's and diabetes. The effect of $P$. latifolia on cholinesterase, $\alpha$-amylase, $\alpha$-glucosidase and tyrosinase are displayed in Table 2. The results concluded that all extracts of $P$. latifolia possess anti-cholinesterase, antidiabetic and anti-tyrosinase activities. In tyrosinase assay, the methanol extract $\left(231.70 \mathrm{mg} \mathrm{KAE} \mathrm{g}^{-1}\right)$ showed the highest inhibitory activity, followed by ethyl acetate (214.61 $\mathrm{mg} \mathrm{KAE} \mathrm{g}^{-1}$ ) and aqueous (26.18 $\mathrm{mg} \mathrm{KAE} \mathrm{g}^{-1}$ ). Tyrosinase plays a crucial role in the biosynthesis of melanin [29]. Nevertheless, an abnormal high level of tyrosinase is associated with several skin diseases such as albinism and skin hyperpigmentation [30]. Hence, the inhibition of tyrosinase may be helpful in cosmetic and pharmaceutical applications.

The ethyl acetate extract exhibited the highest inhibitory effect for all tested enzymes (except tyrosinase). However, aqueous extract exhibited very low enzyme inhibitory effect. For example, the activity of methanol extract was about 9 times of aqueous extract in tyrosinase assay. In the light of the results obtained, the enzyme inhibitory effect of studied extracts was related to total phenolic content. This result is in agreement with previous studies $[31,32]$. No study on the cholinesterase, $\alpha$-amylase, $\alpha$-glucosidase and tyrosinase inhibitory effect of $P$. latifolia leaves has been carried out.

Table 1. Total antioxidant capacity of $P$. latifolia

\begin{tabular}{|c|c|c|c|}
\hline Assays & EA & МeOH & Aqueous \\
\hline DPPH assay (mgTE $\mathrm{g}^{-1}$ extract) & $190.71 \pm 8.73^{* \mathrm{a}}$ & $184.77 \pm 10.03^{\mathrm{a}}$ & $158.04 \pm 5.29^{b}$ \\
\hline ABTS assay (mgTE g $^{-1}$ extract) & $256.77 \pm 52.95^{\mathrm{b}}$ & $278.64 \pm 24.21^{\mathrm{ab}}$ & $347.40 \pm 20.98^{\circ}$ \\
\hline CUPRAC assay (mgTE $\mathrm{g}^{-1}$ extract) & $599.41 \pm 21.36^{\mathrm{a}}$ & $609.38 \pm 4.67^{\mathrm{a}}$ & $575.59 \pm 19.97^{\circ}$ \\
\hline FRAP assay (mgTE/g ${ }^{-1}$ extract) & $356.72 \pm 5.65^{\mathrm{a}}$ & $357.05 \pm 5.55^{\mathrm{a}}$ & $399.09 \pm 6.65^{\mathrm{a}}$ \\
\hline Phosphomolybdenum (mmolTE $g^{-1}$ extract) & $5.62 \pm 0.29^{\mathrm{a}}$ & $3.93 \pm 0.24^{\mathrm{b}}$ & $3.34 \pm 0.06^{\mathrm{c}}$ \\
\hline Metal chelating activity (mgEDTAE $\mathrm{g}^{-1}$ extract) & na & $11.55 \pm 1.01^{\mathrm{b}}$ & $14.83 \pm 0.98^{\mathrm{a}}$ \\
\hline
\end{tabular}

*Values expressed are means \pm S.D., TE: Trolox equivalent; EDTAE: EDTA equivalent, na: not activity; For each solvent, values in the same column bearing different letters are significantly different at $\mathrm{p}<0.05$. 
Table 2. Enzyme inhibitory effect of P. latifolia

\begin{tabular}{|c|c|c|c|}
\hline Assays & EA & МeOH & Aqueous \\
\hline Acetylcholinesterase (mgGALAE $\mathrm{g}^{-1}$ extract) & $4.01 \pm 0.07^{* a}$ & $3.49 \pm 0.09^{\mathrm{b}}$ & $1.51 \pm 0.24^{\mathrm{c}}$ \\
\hline Butyrylcholinesterase (mgGALAE $\mathrm{g}^{-1}$ extract) & $3.95 \pm 0.22^{\mathrm{a}}$ & $2.68 \pm 0.18^{\mathrm{b}}$ & $0.71 \pm 0.19^{\mathrm{c}}$ \\
\hline$\alpha$-Amylase (mmolACE $\mathrm{g}^{-1}$ extract) & $0.43 \pm 0.04^{\mathrm{a}}$ & $0.35 \pm 0.02^{\mathrm{b}}$ & $0.09 \pm 0.01^{\mathrm{c}}$ \\
\hline$\alpha$-Glucosidase (mmolACE $\mathrm{g}^{-1}$ extract) & $1.73 \pm 0.08^{\mathrm{a}}$ & $1.71 \pm 0.01^{\mathrm{a}}$ & $0.68 \pm 0.09^{\mathrm{b}}$ \\
\hline Tyrosinase (mgKAE $\mathrm{g}^{-1}$ extract) & $214.61 \pm 0.72^{\mathrm{b}}$ & $231.70 \pm 1.74^{\mathrm{a}}$ & $26.18 \pm 2.96^{\mathrm{c}}$ \\
\hline
\end{tabular}

*Values expressed are means \pm SD, GALAE: galanthamine equivalets; ACE: acarbose equivalents, KAE: kojic acid equivalents. For each solvent, values in the same column bearing different letters are significantly different at $\mathrm{p}<0.05$.

\section{CONCLUSION}

In brief, the biological properties (antioxidant capacity and enzyme inhibitory effect) of $P$. latifolia leaves were assessed in vitro. This is first report on the study of antioxidant and enzyme inhibitory effect of $P$. latifolia leaves. The results showed that extracts of $P$. latifolia leaves have potent antioxidant and enzyme inhibitory effect. Thus, $P$. latifolia could be used natural antioxidant and enzyme inhibitory. Further studies especially identification of the compounds responsible for biological activity is also important.

\section{KAYNAKLAR}

[1] Kwan I, Embuscado ME. Spices and herbs: natural sources of antioxidants - A mini review. J Funct Foods. 2015; 18(B): 811-819.

[2] Singh B, Singh JP, Kaur A, Singh N. Bioactive compounds in banana and their associated health benefits - a review. Food Chem. 2016; 206: 1-11.

[3] Teinkela, JEM, Noundou XS, Mimba JEZ, Meyer F, Tabouguia OM, Nguedia JCA, et al. Compounds isolation and biological activities of Piptadeniastrum africanum (hook. f.) Brennan (Fabaceae) roots. J Ethnopharmacol. 2020; 255 (12): 112716.

[4] Zengin G, Cvetanović A, Gašić U, Stupar A, Bulut G, Senkardes I, et al. Chemical composition and bio-functional perspectives of Erica arborea L. extracts obtained by different extraction techniques: Innovative insights. Ind Crops Prod. 2019; 142: 111843.

[5] Bastías-Montes JM, Monterrosa K, Muñoz-Fariña O, García O, Acuña-Nelson SM, Vidal-San Martín $\mathrm{C}$, et al. Chemoprotective and antiobesity effects of tocols from seed oil of Maqui-berry: Their antioxidative and digestive enzyme inhibition potential. Food Chem Toxicol 2020; 136: 111036.

[6] Newman DJ, Cragg GM. Natural products as sources of new drugs from 1981 to 2014, J Nat Prod. 2016; 79(3): 629-61.

[7] Niedermeyer TH. Anti-infective natural products from cyanobacteria. Planta Med. 2015; 81 (15): 1309-25.

[8] Dong S, Duan Y, Hu Y, Zhao Z. Advances in the pathogenesis of Alzheimer's disease: a re- evaluation of amyloid cascade hypothesis. Transl Neurodegener. 2012; 1(1): 18.

[9] Kepp, KP. Bioinorganic chemistry of Alzheimer's disease. Chem Rev. 2012;112(10): 5193-239.

[10] Rahman A, Choudhary MI. Drug design and discovery in Alzheimer's disease. 1 st ed. Elsevier, 2015

[11] Maresch CC, Stute DC, Alves MG, Oliveira, PF, de Kretser DM, Linn T. Diabetes-induced hyperglycemia impairs male reproductive function: a systematic review. Hum Reprod Update. 2018; 24(1): 86-105.

[12] Omolaoye TS, Skosana BT, du Plessis SS. Diabetes mellitus- induction: effect of different streptozotocin doses on male reproductive parameters, Acta Histochem. 2018; 120(2): 103-9.

[13] Li ZM, Liu N, Jiang YP, Yang JM, Zheng J, Sun $\mathrm{M}$, et al. Vitexin alleviates streptozotocin-induced sexual dysfunction and fertility impairments in male mice via modulating the hypothalamuspituitary-gonadal axis. Chem Biol Interact. 2019; 297: 119-29.

[14] Cho NH, Shaw JE, Karuranga S, Huang Y, Da Rocha Fernandes JD, Ohlrogge AW, et al. IDF diabetes atlas: global estimates of diabetes prevalence for 2017 and projections for 2045, Diabetes Res Clin Pract. 2018; 138: 271-281

[15] Buchholz T, Melzig MF. Medicinal plants traditionally used for treatment of obesity and diabetes mellitus - screening for pancreatic lipase and $\alpha$-amylase inhibition. Phytother Res. 2016; 30(2): 260-6.

[16] Maelicke A, Samochocki M, Jostock R, Fehrenbacher A, Ludwig J, Albuquerque EX, Zerlin, M. Allosteric sensitization of nicotinic receptors by galantamine, a new treatment strategy for Alzheimer's disease. Biol Psychiat. 2001; 49(3): 279-288.

[17] Kim YJ, Uyama H. Tyrosinase inhibitors from natural and synthetic sources: structure, inhibition mechanism and perspective for the future. Cell Mol Life Sci. 2005; 62(15): 1707-23.

[18] Etxeberria U, de la Garza AL, Campion J, Martínez JA, Milagro FI. Antidiabetic effects of natural plant extracts via inhibition of carbohydrate hydrolysis enzymes with emphasis on pancreatic alpha amylase. Expert Opin Ther Tar. 2012; 16(3): 26997. 
[19] Pieroni A, Pachaly P, Huang Y, Van Poel B, Vlietinck AJ. Studies on anti-complementary activity of extracts and isolated flavones from Ligustrum vulgare and Phillyrea latifolia leaves (Oleaceae). J Ethnopharmacol. 2000; 70(3): 213217.

[20] Diaz AM, Abad MJ, Fernandez L, Recuero C, Villaescusa L, Silvan AM, et al. In vitro antiinflammatory activity of iridoids and triterpenoid compounds isolated from Phillyrea latifolia L. Biol Pharm Bull. 2000; 23(11): 1307-13.

[21] Tuzlacı E, Aymaz PE. Turkish folk medicinal plants, part IV: Gönen (Balıkesir). Fitoterapia. 2001; 72(4): 323-343.

[22] Agati G, Galardi C, Gravano E, Romani A, Tattini M. Flavonoid distribution in tissues of Phillyrea latifolia L. leaves as estimated by microspectrofluorometry and multispectral fluorescence microimaging. Photochem Photobiol. 2002; 76(3): 350-360.

[23] Diaz-Lanza AM, Abad-Martinez MJ, FernandezMatellano L, Recuero Carretero C, Villaescusa Castillo L, Silvan Sen AM, et al. Lignan and phenylpropanoid glycosides from Phillyrea latifolia and their in vitro antiinflammatory activity. Planta Med. 2001; 67(3): 219-223.

[24] Hussain H, Tobji RS. Antibacterial Screning of Some Libyan Medicinal Plants. Fitoterapia. 1997; 68(5): 467-70.

[25] Grochowski DM, Uysal S, Zengin G, Tomczyk M. In vitro antioxidant and enzyme inhibitory properties of Rubus caesius L. Int J Environ Health Res.2019; 29(3): 237-245.

[26] Rutkowska M, Olszewska MA, KolodziejczykCzepas J, Nowak P, Owczarek A. Sorbus domestica leaf extracts and their activity markers: antioxidant potential and synergy effects in scavenging assays of multiple oxidants. Molecules. 2019; 24(12): 2289.

[27] Panche AN, Diwan AD, Chandra SR. Flavonoids: an overview. J Nutr Sci. 2016; Dec 29(5):e47.

[28] Ayranci E, Erkan N. Radical scavenging capacity of methanolic Phillyrea latifolia L. extract: anthocyanin and phenolic acids composition of fruits. Molecules. 2013;18(2): 1798-810.

[29] Chai WM, Huang Q, Lin MZ, Ou-Yang C, Huang WY, Wang YX, et al. Condensed tannins from Longan Bark as inhibitor of tyrosinase: structure, activity, and mechanism. J Agric Food Chem. 2018; 66(4): 908-917.

[30] Oetting WS, King RA. Molecular basis of oculocutaneous albinism. J Invest Dermatol. 1994; 103(5): 131-36.

[31] Rajasekhar A, Peddanna K, Vedasree N, Munirajeswari P, Nagaraju N, Badri KR, et al. Antidiabetic activity of root tubers of Asparagus gonoclados Baker in streptozotocin induced diabetic rats. J Ethnopharmacol. 2019; Oct 5(242): 112027.

[32] Jung M, Park M, Lee HC, Kang YH, Kang ES, Kim SK. Antidiabetic agents from medicinal plants. Curr Med Chem. 2006; 13(10): 1203-18. 